\title{
The Czech Adaptation of Motivated Strategies for Learning Questionnaire (MSLQ)
}

\author{
Jitka Jakešová ${ }^{1}$ \& Karla Hrbáčková \\ ${ }^{1}$ Research Centre, Faculty of Humanities, Tomas Bata University in Zlín, Zlín, Czech Republic \\ ${ }^{2}$ Department of Pedagogical Sciences, Faculty of Humanities, Tomas Bata University in Zlín, Zlín, Czech \\ Republic \\ Correspondence: Jitka Jakešová, Research Centre, Faculty of Humanities, Tomas Bata University in Zlín, nám. T. \\ G. Masaryka 5555, 76001 Zlín, Czech Republic. E-mail: jjakesova@fhs.utb.cz
}

Received: January 15, 2014 Accepted: April 22, 2014 Online Published: May 26, 2014

doi:10.5539/ass.v10n12p72 URL: http://dx.doi.org/10.5539/ass.v10n12p72

\begin{abstract}
The aim of this paper is to provide theoretical and methodological insights into the process of self-regulated learning, and to describe the adaptation of The Motivated Strategies for Learning Questionnaire (MSLQ), developed by Pintrich et al. (1993). This Likert-scaled instrument was designed to assess motivation orientations and use of learning strategies. The adaptation concerned only the first section, the learning strategies section was not part of the adaptation. The motivation scales originally tap into three broad areas: (1) value, (2) expectancy, and (3) affect. In exploratory factor analysis a 3-factor model was generated and good internal consistency of the adapted instrument was achieved. In this version the questionnaire has 27 items with overall reliability of $\alpha=$ 0.83. The alphas for the three subscales range from 0.70 to 0.86 and explaines $35 \%$ of the total variance. The data proved a student's academic self-efficacy (F1), task value (F2) and test anxiety (F3) to be strong predictors of students' motivation.
\end{abstract}

Keywords: motivational aspects of self-regulated learning, properly adapting questionnaires, construct validity, factor analysis, content validity, internal consistency, Cronbach's alpha

\section{Introduction}

Knowing what specifically leads to the formation and development of self-regulated learning, and how this information can be used to support this process in school education, is not only interesting but also beneficial to both theory and practice. This understanding may lead to an improvement in students' study habits, and greater professional competence in teachers; specifically, the acquisition of skills that go beyond the normal boundaries of the profession.

Many studies suggest that self-regulation is represented by a student who directs his/her learning without being directed from outside. What characterizes self-regulating students is their active role in learning from the cognitive, metacognitive, and motivational point of view (Zimmerman, 2002; Průcha, Walterová, \& Mareš, 2003). Additionally, self-regulated students complete their learning tasks better, are more satisfied and successful in school.

Self-regulating skills aren't regarded as inborn mental skills or obtained learning skills; rather they are the self-directive processes by which students transform their mental abilities into academic skills (Zimmerman, 1990, 2002). Past research on self-regulated learning has reflected the following characteristics differentiate self-regulated learners from those who struggle with self-regulation (Winne, 1995; Zimmerman, 1989, 2001, 2002):

1) They know how to use a series of cognitive strategies (elaboration, organization, highlighting information), which help them to organize, transform, recover and elaborate information.

2) They know how to use a series of metacognitive strategies (how to achieve their personal goals by planning, controlling and directing their mental processes).

3) They hold a set of motivational beliefs, such as a high level of academic self-efficacy, internalization of learning goals and development of positive emotional attitude towards tasks (e.g. joy, satisfaction, enthusiasm). 
4) They know how to organize the environment in which they learn (how to restructure a suitable place to study, manage time and effort to achieve the most efficient learning, development and successful completion of academic tasks).

5) They are active in the area of control and regulation of academic tasks and participate in the creation of classroom climate and structure.

6) They know how to regulate a series of volitional strategies to achieve better motivation, concentration and effort to master the academic tasks.

If we summarize what characterizes self-regulated learning is that learning is understood as active process, students are intrinsic motivated, use strategies that allow them to reach desired academic results and they see themselves as agents of their own behavior.

\subsection{Self-Regulated Learning and Research}

Self-regulated learning has been a part of the research activity across all continents in these thirty years. The diversity of views is considerable (Boekaerts, Pintrich, \& Zeidner, 2005; Puustin \& Pulkkinen, 2001; Zimmermann \& Schunk, 2001; Winne, 1995). In the last fifteen years large number of authors of theories and models have seeked to not only identify a key processes affecting self-regulation learning, but to uncover relations and interactions between relevant intervening variables and academic performance.

Self-regulated learning is the current issue of researches authors such as Boekaerts (2002), Pintrich (2002), Zimmerman (1989, 1990, 2002), Zimmerman and Martinez-Pons (1990), Deci and Ryan (2000a, 2000b). In the Czech pedagogical and psychological domains self-regulated learning is represented by Mareš, Man, Prokešová (1996), Mareš (1998), Foltýnová (2009). Studies indicate a relationship between cognitive and metacognitive strategies (Vlčková, 2007; Krykorková \& Chvál, 2001; Hrbáčková \& Vávrová, 2012) and motivation (Urbánek \& Čermák, 1996).

Out of the whole group of self-regulated learning models, Pintrich's model (2000b) of self-regulated learning is highlighted as one of the most important attempts at synthesizing the different activities and processes helping to increase self-regulation in learning. Our study builds on motivational aspects that stand side by side with cognitive and metacognitive aspects as a part of the whole self-regulated learning process.

Pintrich and collaborators have created the Motivated Strategies for Learning Questionnaire (MSLQ) (Pintrich et al., 1991). This assessment instrument is acknowledged by the scholars in the field of self-regulation, and it has also been one of the most applied measures of self-regulated learning in different educational environments (Almegta, 1997; Fuller, 1999; Chan, 2002; Yamauchi, Kumagai, \& Kawasaki, 1999; Lee, 1997). Hereafter, we explain the adaptation of the Pintrich Assessment Instrument for university students and present the first data describing the need to monitor students' academic self-efficacy, test anxiety and task value to achieve academic success and greater professional competence in teachers.

Investing in supporting effective self-regulate learning is one of the priority issues for national European education policies. Resent research on student academic performance has stressed the importance of considering the motivational components of classroom learning. Student's ability to self-regulate learning is increasingly being seen as a good predictor of a student's academic success. Nevertheless, very little empirical research has examined this field of interest. The present study seeks to address this gap in the literature.

On this basis it is possible to present the first data describing the level of the motivational aspects of self-regulated learning in the Czech educational environment, that according to present research (Boekaerts, 2002; Pintrich, 2002; Zimmerman et al., 2008; Hrbáčková et al., 2011), seem to be the strongest factors influencing development of self-regulated learning. In general, the study focuses on the motivational aspects of self-regulated learning that were measured in university students of auxiliary services professions $(n=238)$. The research into the process of self-regulated learning is a response to the current need to equip future graduates with other skills beyond their field of study-skills that are increasingly important in today's workplace, including findings how independent learning is regulated, and how to educate others in this process.

In our context, the MSLQ questionnaire has been translated and adapted by Jakešová, distributed under the name of MoSU (Dotazník motivačních strategií učení).

\section{Methodology of Research}

The MSLQ has been under development since 1986. Usual statistical and psychometric analyses of the items were tested, and correlated with results of academic performance. Tested version of the MSLQ adapted in the Czech educational environment is an 81-item self-report instrument that contains the past 10 years of work. The 
questionnaire consists of two main sections, a motivation section (items 1 to 31), and a learning strategies section (items 32 to 81). Items are scored on a 7-point Likert scale, where 1 means not at all true for me and 7 means very true of me. The average of all items obtain the total score of self-regulated learning, where achieving a higher score means achieving higher levels of self-regulated learning. An individual's scores for the appropriate subscales would be computed by summing items and taking the average. Ratings of negatively worded items have to be reversed before score is computed.

The MSLQ is designed to measure university students' motivational orientations and their use of various learning strategies (Pintrich at al., 1991). Social-cognitive theory underlines structure of MSLQ and proposes three general constructs (Pintrich at al., 1993): (1) value, (2) expectancy, and (3) affect. Value components focus on finding reasons why students work on academic task. Three subscales were constructed to measure value beliefs: intrinsic goal orientation (representing a focus on learning and mastery), extrinsic goal orientation (representing a focus on good academic performance in the form of good grades and feeling to be exceptional from others), and task value beliefs (representing course evaluation of the importance, usefulness and interesting for students). Expectancy components refer to students' beliefs that they are able to successfully complete a task. Two subscales are included in the MSLQ to assess students' receptions of academic self-efficacy and control beliefs for learning. The last general motivational construct is affect including the test anxiety items responses, which concerns students concern and worry over their failure in taking exams. MSLQ was tested and validated in different educational environments for a variety of student population, both university and non-university levels.

This study explores the factors underlying students' motivation in process of self-regulated learning. The motivation is presented by 6 factors in the original MSLQ English-language written instrument. Within the presented adaptation study, first of all, translation was made, interim use of the scale has been tested and validity and reliability analyses has been applied to the acquired data in SPSS Statistic Base 21.

268 students (Note 1) of the Faculty of Humanities at Tomas Bata University in Zlín participated in the survey at the end of Spring 2013 semester. 238 valid cases (226 women and 12 men) were analyzed. Out of that number, 179 students were daily students and 59 students were part-time students of social pedagogy specialization (average age was 24, running from 19 to 48, standard deviation 6.2 years).

The aim of the presented study was to verify if the selected scales had satisfactory construct validity using factor analysis, Catell's scree test, Monte Carlo analysis and additionally content validity. Internal consistency of the questionnaire and the partial factors were examined answering if the research instrument was sufficiently reliable. Principal Component (PCA) for the different factors solution was analyzed with an interpretable structure with items clustered into three Underlying factors. To select individual scales we set up following criteria:

1) to exclude all items that correlated 0.3 or less with the total scale;

2) to exclude all items with means less than 1.75 and more than 6.25;

3 ) to exclude all items with low factor loadings less than 0.55 ;

4) to exclude all items with low consensus of the judges (with means less than 2.5);

5 ) to exclude all recurring items based on descriptive statistics.

MSLQ was translated into Czech by the authors with the control of an expert in the field of English language and Education. Using the instrument in a different educational environment is often provided with different items' suitability in this environment. Therefore the final version of the instrument often has a different number of items than the original version contains before translation. The researcher creates (besides the original items) new items to function optimally and to fit appropriately into the dimensions of the questionnaire. It is expected that not all items will ideally work in the Czech educational environment. Their subsequent reduction is therefore highly probable.

\section{Analysis and Results}

At this stage we created a tray of relevant items that expanded the original version of the questionnaire. Meanwhile those items are just a theoretical construct generated with no practical responses that can be achieved through pilot testing. The original number (31 items) was increased up to a total of 70 items. A test version of the questionnaire was subsequently presented in pilot testing to the first respondents, and evaluated.

\subsection{Validity of the Instrument}

Assessing construct validity factor analysis was performed. To validate that the data set is a good fit for factor analysis the Kaiser-Meyer-Olkin Measure of Sampling Adequacy (KMO) value of 0.6 is a suggested minimum 
$(\mathrm{KMO}=0.844)$, the Bartlett's Test of Sphericity significantly smaller than $0.05\left(\mathrm{x}^{2}=8515.369 ; \mathrm{df}=2415 ; \mathrm{p}<\right.$ 0.000 ) and Determinant is not 0 , therefore factor analysis was appropriate.

To be able to determine how many components (factors) to extract we were interested only in factors that have an eigenvalue of 1 or more, labeled Kaiser's criterion. The Total Variance Explained table lists the eigenvalues for each component. In this case, the first 17 components recorded eigenvalues above 1 (from 13.647 to 1.047) and explained a total of $66 \%$ of the variance. Often, too many components are extracted meeting the Kaiser criterion. Therefore, the Scree plot was checked and recommended to retain (extract) only three or sixth factors.

The factor analysis failed to reach the significant dimensions' composition in the first round of extraction interpretative factors. To get more interpretable and clear results, the rotation was used. Based on the inspection of the Scree plot (recommended to retain three or sixth factors) sixth factors rotation was performed to identified significant factors.

Orthogonal rotation Varimax was chosen (assumes uncorrelated factors) performed with the 70 items. In Varimax rotation, each factor will tend to have either large or small loadings on any particular variable (Muijs, 2011). Rotated solution did not help either in interpretation. Conversely, more items had a relatively strong correlation in two or more factors, so the interpretation of factors would be difficult. Also the fifth factor did not extracted any items and in the fourth and sixth factor were only two items, which does not meet the rule making independent factor containing a minimum of three items.

According to inspection of the Scree plot the three-factor solution was employed and one more tactical move was accepted, i.e. exclude all low factor loadings items (less than 0.55) (Note 2) or items being loaded in more than one factor at the time. Three extracted factors explain 35\% variance (see table 2) and the number of items was reduced from 70 to 32 (38 items were excluded due to low factor loadings). The items fit only into one extracted factors and each item is given adequate content (interpretable) factor. Factor 1 academic self-efficacy (11 items) accounted for most of the total variance of 19.49\%. Factor 2 task value (12 items) accounted for 9.91\% variance and Factor 3 test anxiety (9 items) accounted for 5.93\% variance.

Table 2. Total variance explained

\begin{tabular}{|c|c|c|c|c|c|c|c|c|c|}
\hline \multirow{2}{*}{ Factor } & \multicolumn{3}{|c|}{ Initial Eigenvalues } & \multicolumn{3}{|c|}{ Extraction Sums of Squared Loadings } & \multicolumn{3}{|c|}{ Rotation Sums of Squared Loadings } \\
\hline & Total & $\%$ of Variance & Cumulative \% & Total & $\%$ of Variance & Cumulative $\%$ & Total & $\%$ of Variance & Cumulative $\%$ \\
\hline 1 & 13.647 & 19.496 & 19.496 & 13.647 & 19.496 & 19.496 & 9.536 & 13.623 & 13.623 \\
\hline 2 & 6.942 & 9.917 & 29.413 & 6.942 & 9.917 & 29.413 & 8.786 & 12.551 & 26.174 \\
\hline 3 & 4.151 & 5.930 & 35.343 & 4.151 & 5.930 & 35.343 & 6.418 & 9.169 & 35.343 \\
\hline 4 & 2.554 & 3.648 & 38.991 & & & & & & \\
\hline 5 & 2.258 & 3.226 & 42.217 & & & & & & \\
\hline
\end{tabular}

Extraction Method: Principal Component Analysis.

* Due to the length shortened. The initial number of factors (components) is the same as the number of variables used in the factor analysis, i.e. 70 factors.

The selected items of individual factors were further analyzed for their content validity on a consensus of the judges who evaluated the degree to which items by their content fit into a given factor from 1 (least accurate) to 5 (most accurate). All items that did not correspond with a given factor (with a low average score) were excluded. Based on this analysis, 3 items (two items from the second factor and one item from the first factor) were excluded with an average core lower than 2.5 points (Note 3 ).

Construct validity and content validity results, however, failed occurrence of identical formulations of the items in the questionnaire, where the reduction of one or the other items is suitable. The subjective view of the researcher and the descriptive characteristics of the items were considered, which takes decisions of the final form of the survey instrument back into researcher hands. In this evaluation two items (one item from the first factor and one item from the second factor) were excluded. All together 27 items were adopted.

It is interesting to determine the dominant "functioning" of new items (created by Czech researchers) over the original items from the MSLQ questionnaire. Those items were evaluated as easier to answer and more natural for students than the original items coming from a foreign education environment. The three motivational scales (3-factor model) measure three general components of university students' motivation that seem to be 
independent factors.

\subsection{Reliability of the Instrument}

The coefficient Cronbach's alpha for all 27 items reached 0.83, demonstrating good internal consistency. Students' judgments of their academic self-efficacy for learning and performance reached the internal consistency of alpha 0.86. Task value beliefs concerning students' ratings about how useful, interesting and important the course is to them also proved to be internally consistent $(\alpha=0.70)$ and the test anxiety yielded the internal consistency of $\alpha=0.86$. Taken together, the factor analysis and reliability of Cronbach's alpha for the tested items suggest that the general model of motivational components with three scales is a reasonable representation of the data.

\subsection{Factor Interpretation of the Findings}

For the structural interpretation of the factors, only loadings reached the significant level were considered. As far as factor one is considered, a close inspection of the loading order and items meaning indicates that items concerned the belief that a student has about his/her own abilities due to the learning process. It is also defined as the belief that the student subjectively evaluates his/her potential to perform in some level of success doing certain activities. Student with a positive expectation about his/her effectiveness in school achievement tends to attribute intrinsic interest to activities and pursue then and to approach difficult tasks as challenges. Overall, the all-encompassing label given to this factor is academic self-efficacy (No. of items: $10, \alpha=0.86$, mean $=4.84$ ).

For the loading order and number categories pulled together into factor 2, it was interpreted as the task value and the necessity and usefulness of the course. A student shows greater interest in learning, if he/she considers content of the course valuable. The engagement process of self-regulated learning is rising, if the activities are perceived as meaningful and inducing personal interest to be part of it and if he/she sees it as beneficial. The conviction of the high value of the task leads to better engage students in their own learning process, as the tasks perceived as interesting, helpful and useful. Thus, the label found to precisely capture the content validity of this factor was task value (No. of items: $9, \alpha=0.70$, mean $=4.77$ ).

The items loading into factor 3 are experiencing anxiety related to the prevalence of stress in personal and in professional life. Anxiety can cause such excessive demands from parents and schools, competition, fear of failure and a sense of inability to cope with the resulting pressure. Factor expresses the feelings of anxiety that student experiences during the challenging period of study, which is primarily the examination period of the semester. Since the factor includes aspects of the pressure of anxiety, it was labeled test anxiety (No. of items: 8 , $\alpha=0.86$, mean $=4.05$ ).

\section{Discussion}

The results suggest that the Czech version of the MSLQ questionnaire has relatively good reliability in terms of internal consistency. The scales measuring general theoretical framework seem to be valid given the results of the three exploratory factor analyses. Those three motivational subscales represent a conceptual, coherent and empirically validated base for assessing student motivation in the university classroom. Although it differs from the original number of factors MSLQ questionnaire presents, 3-factor solution fits the best (i.e. those factors are underlying students' motivation in process of self-regulated learning) into the Czech educational environment. The new version of MSLQ questionnaire is represented by 27 items (see Appendix). Factor $1\left(\mathrm{~F}_{1}\right)$ academic self-efficacy included 10 items, factor $2\left(\mathrm{~F}_{2}\right)$ task value included 9 items, factor $3\left(\mathrm{~F}_{3}\right)$ test anxiety included 8 items. The MoSU seems to represent a reliable, valid and useful instrument for assessing university students' motivation for learning.

Due to its thematic focus, the research fits into current national and international intention, which seeks to find a new conception of education based on the purposeful linking of theory and practice. It focuses on a neglected area of research, research on the construction and development of self-regulated learning in university students. Differences in various standards of students' motivation in process of self-regulated learning according to one's gender, type of study, form of study, specialization and successfulness in one's studies will be further analyzed, as well as relations among all the examined factors.

\section{References}

Almegta, N. R. (1997). Relationship of self-efficacy, causal attribution and emotions to female college students' academic self-evaluations. In C. S. Chen (Ed.), Information Technology, Learning, and Performance Journal (pp. 11-25). Morehead: OSRA.

Boekaerts, M. (2002). Motivation to learn. Geneva: International Bureau of Education. 
Boekaerts, M., Pintrich, P. R., \& Zeidner, M. (Eds.). (2005). Handbook of self-regulation. San Diego: Academic Press.

Chan, K. (2002). Teacher education students' epistemological beliefs and their relations with conceptions of learning and learning strategies. The Asia Pacific-Education Researcher, 16(2), 199-214.

Deci, E. L., \& Ryan, R. M. (2000a). Intrinsic and extrinsic motivations: Classic definitions and new directions. Contemporary Educational Psychology, 25(1), 54-67. http://dx.doi.org/10.1006/ceps.1999.1020

Deci, E. L., \& Ryan, R. M. (2000b). Self-Determination theory and the facilitation of intrinsic motivation, social development, and well-being. American Psychologist, 55(1), 68-78. http://dx.doi.org/10.1037/0003066X.55.1.68

Foltýnová, D. (2009). Vliv metakognitivních strategií na rozvoj dovedností žáků autoregulovat své učení. Pedagogická orientace, 19(2), 72-88.

Hrbáčková, K. (2011). Development of the Czech Version of the Questionnaire on Self-Regulated Learning of Students. The New Educational Review, 26(4), 33-44.

Hrbáčková, K., \& Vávrová, S. (2012). Subjective Conception of Students' Self-Regulated Learning from the Perspective of a Beginner Teacher. Asian Social Science, 8(10), 228-239. http://dx.doi.org/10.5539/ ass.v8n10p228

Krykorková, H., \& Chvál, M. (2001). Rozvoj metakognice-cesta k hodnotnějšímu poznání. Pedagogika, 51(2), 185-196.

Lee, L. H. (1997). Goal orientation, goal setting, and academic performance in college students: An integrated model of achievement motivation in school settings. Dissertation Abstracts International, 59(6), 1905A.

Mareš, J. (1998). Styly učení žáků a studentů. Praha: Portál.

Mareš, J., Man, F., \& Prokešová, L. (1996). Autonomie žáka a rozvoj jeho osobnosti. Pedagogika, 46(1), 5-17.

Mareš, J., Slavík, J., Svatoš, T., \& Švec, V. (1996). Učitelovo pojetí výuky. Brno: Masarykova univerzita.

Mascitelli, R. (2000). From Experience: Harnessing Tacit Knowledge to Achieve Breakthrough Innovation. Journal of Product Innovation Management, 17(3), 179-193. http://dx.doi.org/10.1016/S0737-6782 (00)00038-2

Muijs, D. (2011). Doing quantitative research in education with SPSS. London: Sage Publications Ltd.

Pallant, J. (2010). SPSS survival manual: A step by step guide to data analysis using SPSS. Maidenhead, Berkshire: Open University Press.

Pintrich, P. R. (2000). The role of goal orientation in self-regulated learning. In M. Boekaerts, P. R. Pintrich, \& M. Zeidner (Eds.), Handbook of self-regulation (pp. 451-502). San Diego, CA: Academic Press. http://dx.doi.org/10.1016/B978-012109890-2/50043-3

Pintrich, P. R. (2002). The role of metacognitive knowledge in learning, teaching, and assessing. Theory Into Practice, 41(42), 219-226. http://dx.doi.org/10.1207/s15430421tip4104_3

Pintrich, P. R. (Ed.). (1991). A manual for the use of the Motivational strategies for learning questionnaire (MSLQ). Ann Arbor: University of Michigan, School of Education.

Pintrich, P. R. (Ed.). (1993). Reliability and predictive validity of the motivated strategies for learning questionnaire (MSLQ). Educational and Psychological Measurement, 53(3), 801-814. http://dx.doi.org/ $10.1177 / 0013164493053003024$

Průcha, J., Walterová, E., \& Mareš, J. (2003). Pedagogický slovník. Praha: Portál.

Puustinen, M., \& Pulkkinen, L. (2001). Models of self-regulated learning: A review. Scandinavian Journal of Educational Research, 45(3), 269-286. http://dx.doi.org/10.1080/00313830120074206

Štech, S. (1994). Co je to učitelství a lze se mu naučit? Pedagogika, 44(4), 310-320.

Sternberg, R. J. (2004). Múdri nie sú hlúpi, ale môžu byt' nerozumní. In V. Švec (Ed.), Tacitní znalosti jako most mezi teorií a praxí v pedagogické př́pravě budoucích učitelů (pp. 387-403). Brno: Česká pedagogická společnost.

Stuchlíková, I. (2005). Implicitní znalosti a intuitivní pojetí v pedagogické praxi. In V. Švec (Ed.), Od implicitních teorii výuky k implicitním pedagogickým znalostem (pp. 9-16). Brno: Paido. 
Švec, V. (2006). Implicit Knowledge-a New Phenomenon in Teacher Education. The New Educational Review, 10(3-4), 183-194.

Urbánek, T., \& Čermák, I. (1996). Self-efficacy dětí ve školní činnosti. In Osobnost v dimenzích poruchové a neporuchové činnosti: sbornik př́spěvků z konference $k$ nedožilým 90. narozeninám prof. PhDr. Roberta Konečného, Csc. Brno: Vydavatelství MU a PsÚ AV ČR.

Vlčková, K. (2007). Strategie učení cizímu jazyku: Výsledky výzkumu použivání a efektivity strategií na gymnáziích. Brno: Paido.

Winne, P. H. (1995). Inherent details in self-regulated learning. Educational Psychologist, 30, 173-187. http://dx.doi.org/10.1207/s15326985ep3004_2

Yamauchi, J., Kumangai, Y., \& Kawasaki, Y. (1999). Perceived control, autonomy and self-regulated learning strategies among Japanese High School Learners. Psychological Reports, 85(3), 779-798. http://dx.doi.org/ 10.2466/pr0.1999.85.3.779

Zimmerman, B. J. (1989). A social cognitive view of self-regulated academic learning. Journal of Educational Psychology, 81(3), 329-339. http://dx.doi.org/10.1037/0022-0663.81.3.329

Zimmerman, B. J. (1990). Self-regulated learning and academic achievement: An overview. Educational Psychologist, 25(1), 3-17. http://dx.doi.org/10.1207/s15326985ep2501_2

Zimmerman, B. J. (2001). Theories of self-regulated learning and academic achievement: An overview and analysis. In B. J. Zimmerman, \& D. H. Shunk (Eds.), Self-regulated learning and academic achievement: Theoretical perspectives. New Jersey: Lawrence Erlbaum Associates.

Zimmerman, B. J. (2002). Becoming a self-regulated learner: An overview. Theory into Practice, 41(2), 64-70. http://dx.doi.org/10.1207/s15430421tip4102_2

Zimmerman, B. J. (Ed.). (2008). Motivation and self-regulated learning: Theory, research, and applications. New York, London: Routledge.

Zimmerman, B. J., \& Manuel Martinez-Pons. (1990). Student differences in self-regulated learning: Relating grade, sex, and giftedness to self-efficacy and strategy use. Journal of Educational Psychology, 82(1), 51-59. http://dx.doi.org/10.1037/0022-0663.82.1.51

Zimmerman, B. J., \& Schunk, D. H. (Eds.). (2001). Self-regulated learning and academic achievement: Theoretical perspectives. Hillsdale, NJ: Erlbaum.

\section{Notes}

Note 1. Minimum range of subjects (sample size of questionnaire respondents) in factor analysis is $>150$ cases (Pallant, 2010) and the ratio of sample size to number of measurement constructs should not be less than 2:1. In this case $(n=238)$ is the ratio of 3.4: 1 . The sample represented students of all classes of bachelor and master's degree studies.

Note 2. We conducted a series of extraction of three factors with different correlation coefficients (in the range of 0.30 to 0.60 ). As the most transparent and interpretable extraction was appeared extraction with factorial loadings 0.55 and more.

Note 3. Exclusion of the items Were carried out by calculating the mean score representing engaging specific items under the factor. Items below the average of 2.5 points (range 1 to 5) were excluded.

\section{Copyrights}

Copyright for this article is retained by the author(s), with first publication rights granted to the journal.

This is an open-access article distributed under the terms and conditions of the Creative Commons Attribution license (http://creativecommons.org/licenses/by/3.0/). 